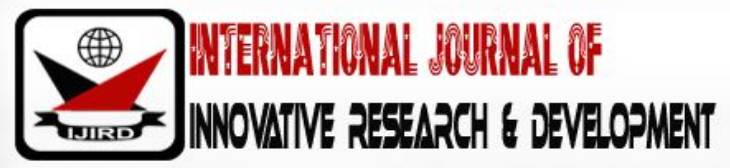

ISSN 2278 - 0211 (Online)

\section{Drug Sensitivity of T. b. Brucei Stabilates from Livestock in Lamu County, Kenya}

\begin{tabular}{|c|}
\hline $\begin{array}{l}\text { Gathogo Miriam } \\
\begin{array}{c}\text { Entomologist, Kenya Forestry Research Institute, Egerton University, Kenya } \\
\text { Shivairo Robert }\end{array} \\
\text { Senior Lecturer, Egerton University, Kenya } \\
\text { Muleke Charles } \\
\text { Professor, Egerton University, Kenya } \\
\text { Mdachi Raymond } \\
\text { Mukiria Phoebe } \\
\text { Research Scientist, Kenya Agricultural and Livestock Research Organization, Kenya } \\
\text { Wesearch Scientist, Kenya Agricultural and Livestock Research Organization, Kenya } \\
\text { Wanyonyi Bernard } \\
\text { Technologist, Kenya Agricultural and Livestock Research Organization, Kenya } \\
\text { Sayah Abiud } \\
\text { Biometrician, Kenya Forestry Research Institute, Kenya } \\
\text { William Limo } \\
\text { Part time Lecturer, Egerton University, Kenya } \\
\text { Gachie Peter } \\
\text { Kenearch Scientist, Kenya, Kenya Forestry Research Institute, Kenya }\end{array}$ \\
\hline
\end{tabular}

\begin{abstract}
:
Four trypanosome stabilates previously identified by PCR as T. b. brucei were isolated from livestock in Lamu and tested for drug sensitivity. The stabilates were grown in mice and characterized as either sensitive or resistant using a single dose of; Isometamidium $\left(1.0 \mathrm{mgkg}^{-1}\right)$, Diminazene $\left(20 \mathrm{mgkg}^{-1}\right)$ or Homidium $\left(1.0 \mathrm{mgkg}^{-1}\right)$. Effective and curative doses were noted and evaluated through t-test and bio-assay descriptive graphical analyses. Clinical changes and mortality, Packed Cell Volume (PCV), parasitaemia and weight changes were monitored for 60 days post infection. KETRI 4028 responded to Isometamidium and Diminazene. KETRI 4032, KETRI 3985 and KETRI 3984 were resistant. Results indicated presence of T. b. brucei sub populations circulating in Lamu with multiple resistance to drugs used and $25 \%$ of sub-population of T. b. brucei that may be sensitive to Isometamidium and Diminazene. Homidium should be discouraged while use of Diminazene and Isometamidium should be used with caution.
\end{abstract}

Keywords: Lamu County, T. b. brucei, drug sensitivity

\section{Introduction}

AT has been found responsible for major socio-economic and public health problems in affected regions. In animals, infection with trypanosomes usually result in a chronic, debilitating and more often than not a fatal disease but the outcome of the infection differs between trypanosome species, between and within livestock species, depending on pathogenicity and virulence of trypanosome strains (Connor and van Den Bossche, 2004). T. congolense, T. vivax and T. simiae are known to be present in Kenyan coast. Boni and Dondori game reserves are an important source of tsetse blood meals, potential reservoir hosts and where livestock encounter a high tsetse and trypanosomiasis challenge. Studies have shown that frequent exposure to drugs in the field promotes gene mutation among the trypanosome parasites leading to drug resistance (Kagira and Maina, 2007). Records from the veterinary department indicate that there is a high level of trypanocidal drug use in Coastal belt. Since the disease prevalence is still high in domestic animals (Murilla et al., 2010) it is not clear whether this is due to drug resistance which has been demonstrated elsewhere in the coast (Murilla et al., 2014). Farmers in this region have been experiencing treatment failure attributable arguably to improper trypanocidal drugs use, resistance development and poor 
qualities of trypanocidals (Ashiembi, 2013) with which farmers administer themselves. Some other factors which relate to the farmer and the parasite have been identified as contributing to treatment failure (Mdachi et al., 2006b) which is key in Coastal region. In an earlier study, despite presence of drug resistant trypanosomes in Lamu District, prophylactic and therapeutic drugs are still effective and hence, by use of quality drugs correctly, trypanosomosis can be effectively controlled (Mdachi et al., 2006a).

\section{Materials and Methods}

\subsection{Experimental Animals}

Two hundred normal healthy white Swiss mice weighing between 20-30g were obtained from BioRI-KALRO Small Animal Breeding Unit (SABU). They were dewormed subcutaneously using injectable ivermectin ${ }^{\circledR}$ at $0.01 \mathrm{ml}$ per mouse and were housed in cages designed for mice with 6 mice per cage and wood chippings as bedding material. The animals were acclimatized for 14 days during which they were maintained on mice pellets (mice pellets ${ }^{\circledR}$, Unga Ltd, Nairobi, Kenya) and water provided ad libitum at room temperature. All experimental procedures and protocols involving mice were accordingly reviewed by Institutional Animal Care and Use Committee (IACUC) of BioRI-KALRO and approved.

\subsection{Trypanosome Isolates}

Four trypanosome stabilates previously identified by PCR as T. b. brucei isolated from a goat (KETRI 4032) and donkeys (KETRI 4028, KETRI 3984 and KETRI 3985) in 2007 and 2014 in different villages in Lamu County were used in this study. The stabilates have been cryopreserved in liquid nitrogen at $-196^{\circ} \mathrm{C}$ at the Kenya Agricultural and Livestock Research Organization-Biotechnology Research Institute- (KALRO-BioRI-) trypanosome bank. The stabilates had been collected from infected donkeys and goats in Lamu County during 2007-2014 epidemiological survey. The four were secondary stabilates (prepared after passaging in mice, restabilated and given the KETRI code).

\subsection{Animal Identification}

Body markings were made to avoid errors during recording of data and ensure accurate records and analysis. Different anatomical areas in the body were marked using picric acid solution using dipsticks with cotton.

\subsection{Multiplication of Trypanosome Stabilates in Donor Mice and WBF Preparation}

For each of the four stabilates, two donor mice were immunosuppressed using cyclophosphamide at 0.2ml per mouse for 3 consecutive days before infection (Kagira et al 2005). On the third day of the cyclophosphamide injection, two capillaries of each stabilate were retrieved from liquid Nitrogen in trypanosome cryobank and placed in a beaker containing ice and allowed to thaw slowly. The thawed stabilates were aspirated into a $1 \mathrm{ml}$ syringe and made up to $0.4 \mathrm{~mL}$ using EDTA saline Glucose (ESG-PH 8.0). Wet Blood Films (WBF) on slides were prepared, then Giemsa ${ }^{\circledR}$ (Medic Diagnostic Reagents) stained. These slides were examined under a microscope at high power (40x) and oil immersion (100x) objectives (Waren et al., 2011a) to identify motile trypanosomes amongst the four T. b. brucei stabilates studied.

Each of the two donor mice were injected intraperitoneally with $0.2 \mathrm{ml}$ of this inoculum. The donor mice were monitored for parasitaemia from day 2 post infection via microscopy (Korir et al., 2013). Parasitaemia was scored using the matching method of Herbert and Lumsden 1974 (Kobo et al., 2014). When parasitaemia level reached antilog 8.1-8.4, blood enough to fill a capillary tube was harvested individually (for each mice) from the tail vein and diluted appropriately to make an inoculum for infecting experimental mice.

\subsection{Infection and Treatment of Experimental Mice for Drug Sensitivity}

At peak parasitaemia, blood was drawn from tail vein donor mice which was diluted ten times (1:10) with ESG at PH 8.0. The number of parasites in the inoculum was quantified using a hemo-cytometer. Further dilutions were made to $5 \times 10^{5}$ trypanosomes/ ml.

There were 4 groups of 6 mice each per stabilate (Table 1). Each experimental mouse was intraperitoneally injected with $0.2 \mathrm{ml}$ of this inoculum containing $1 \times 10^{5}$ trypanosomes/ml. Drug dosage used was as described by Geerts et al 2001 . Experimental mice were treated on day 1 post infection with a single dose of Isometamidium Chloride (Samorin ${ }^{\circledR}$ ),

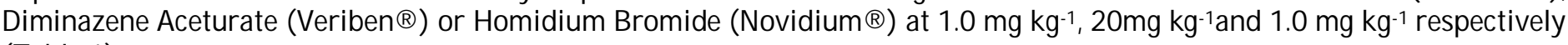
(Table 1).

\begin{tabular}{|llccc|}
\hline & Group & Drug & Dose (mg/ kg body weight) & No of mice \\
\hline 1 & Isometamidium & 1.0 & 6 & \\
2 & Diminazene & 20.0 & 6 & \\
3 & Homidium & 1.0 & 6 & \\
4 & Controls & distilled water & 6 & \\
\hline
\end{tabular}

Table 1: Dose Regimens for Drug Sensitivity Evaluation 
As described by Korir et al., 2013, a trypanosome stabilate was considered drug sensitive if at least $80 \%$ treated mice were cured. In this study if fewer than five mice were cured, the stabilate in question was considered drug resistant. I.e. Resistant stabilates are from 0/ 6 - 4/ 6 while sensitive stabilates are from 5/ 6-6/ 6 (Kagira and Maina, 2007).

\subsection{Monitoring the PCV, Parasitaemia, Body Weight and Mortality in Experimental Mice}

Pre-infection levels of packed cell volume (PCV), body weight and clinical observations on fur state, feed intake and emaciation for both experimental and untreated control mice were collected once a week for two weeks prior to infection. After the mice were infected and subsequently treated $24 \mathrm{hrs}$. later, parasitaemia was monitored daily by microscopic examination of wet smears (Kobo et al., 2014) which involved using a drop of blood from the mouse tail placed on a clean slide and covered with a cover slip, parasites were counted under a microscope for the first 14 days then weekly for the rest of 60 days through Buffy Coat Technique (BCT). Parasitaemia was scored according to the commonly used matching method of Herbert and Lumsden 1974 (Kobo et al., 2014). PCV of experimental mice was determined through hematocrit centrifugation technique (HCT) (Shimelis et al., 2008). Blood enough to fill $3 / 4$ of a capillary was collected from the tail vein using a heparinized capillary tube and completely sealed with plasticin (Korir et al., 2013). The sealed capillaries were centrifuged in a hematocrit centrifuge at 10,000rpm, for 5 minutes. PCV was read using a hematocrit reader then expressed as percentage (\%) of the total blood volume (Naessens et al., 2005). Body weight of experimental mice was monitored weekly using an analytical balance (Mettler Tolendo PB 302 r, Switzerland) (El-arab et al., 2006) and expressed to the nearest grams. Mortality of mice was monitored daily. Surviving mice were monitored for 60 days (Korir et al., 2013) and any experimental mice which experienced breakthrough infections during this period were humanely euthanized. Post infection data collected was subsequently entered in Ms Excel spreadsheets and cleaned. Graphs were used to show how trends of PCV, parasitaemia and how body weights unfolded.

\section{Results}

Pre-infection results and wet blood films of donor mice infected with stabilates

During pre-infection, generalized increase in all parameters used in drug sensitivity tests including weight, PCV and parasitaemia was observed. When Wet Blood Films (WBF) were examined $24 \mathrm{~h}$ post infection in donor mice for drug sensitivity studies, there was absence of trypanosomes until $48 \mathrm{~h}$ post infection for KETRI 4028, KETRI 3984 while the rest of the trypanosome species studied, motile trypanosomes were observed 3 days and 4 days post infection for KETRI 3985 and KETRI 4032 respectively. The following WBF captions (Figure 1) were taken under microscope (Olympus 1 X 51 UTV05XC-3 Japan and Nikon UFX-DX- Japan).

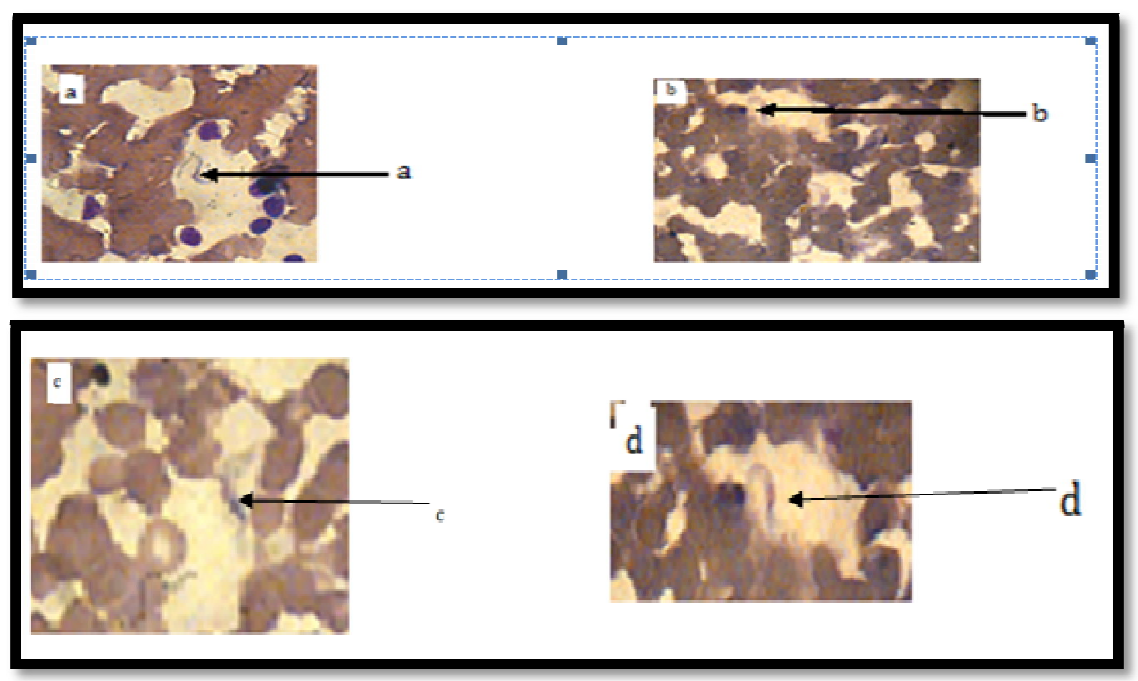

Figure 1: Wet Blood Smears of Four Viable Trypanosome Stabilates in Experimental Mice Used for Drug Sensitivity Test. Key: A. KETRI 3985; B. KETRI 4032; C. KETRI 4028; D. KETRI 3984

\subsection{Drug Sensitivity Testing}

Results on drug sensitivity test in mice are summarized in Table 2. Mice infected with KETRI 4028 were cured by Isometamidium $1 \mathrm{mg} / \mathrm{kg}$ and Diminazene $20 \mathrm{mg} / \mathrm{kg}$. These two drugs cured $100 \%$ of the mice and Homidium cured less than $80 \%$ of the mice infected with KETRI 4028. The other three stabilates (KETRI 4032, KETRI 3984 and KETRI 3985) were resistant to all the three drugs. Mice that were not cured following treatment with the three drugs relapsed on different days as shown in Table 2. Homidium treated mice that were infected with KETRI 4028 took significantly longer to relapse (34 days) than the mice infected with the other three stabilates (7,13 and 20 days). 


\begin{tabular}{|l|l|l|l|l|l|l|}
\hline \multirow{2}{*}{ Isolate identity } & \multicolumn{3}{|c|}{ Number of mice cured } & \multicolumn{3}{c|}{ Relapse time (days ) } \\
\cline { 2 - 7 } & $\begin{array}{l}\text { Isometamidiu } \\
\mathrm{m} 1 \mathrm{mg} / \mathrm{kg}\end{array}$ & $\begin{array}{l}\text { Homidium } \\
1 \mathrm{mg} / \mathrm{kg}\end{array}$ & $\begin{array}{l}\text { Diminazene } \\
20 \mathrm{mg} / \mathrm{kg}\end{array}$ & $\begin{array}{l}\text { Isometamidium } \\
1 \mathrm{mg} / \mathrm{kg}\end{array}$ & $\begin{array}{l}\text { Homidium } \\
1 \mathrm{mg} / \mathrm{kg}\end{array}$ & $\begin{array}{l}\text { Diminazene } \\
20 \mathrm{mg} / \mathrm{kg}\end{array}$ \\
\hline KETRI 4032 & $2 / 6$ & $1 / 6$ & $1 / 6$ & 13 & 7 & 14 \\
\hline KETRI 3985 & $0 / 6$ & $0 / 6$ & $0 / 6$ & 13 & 20 & 14 \\
\hline KETRI 3984 & $2 / 6$ & $0 / 6$ & $0 / 6$ & 41 & 13 & 27 \\
\hline KETRI 4028 & $6 / 6$ & $4 / 6$ & $6 / 6$ & 0 & 34 & 0 \\
\hline
\end{tabular}

Table 2: Sensitivity of Different Isolates to Different Trypanocidal Drugs

\subsection{Clinical Signs}

Prior to infection, mice showed normal body conditions but after infection, treatment and relapsing depending on the stabilate and the drug used for treatment, the mice showed varying body conditions. The following plates show captions taken in the course of the study. Mice infected with KETRI 3985 and KETRI 3984 stabilates showed raised hair coat, lethargy, facial and scrotal edema as the disease progressed and also reduced feed intake was observed. Mice infected with KETRI 4032 and KETRI 4028 and treated with different drugs manifested minimal clinical signs of the disease. Isometamidium $1 \mathrm{mg} / \mathrm{kg}$ treated mice infected with any of the four stabilates were least affected by clinical sign studied as shown in figure 2 . The infected mice showed no clinical signs until 96 - $120 \mathrm{~h}$ post infection.
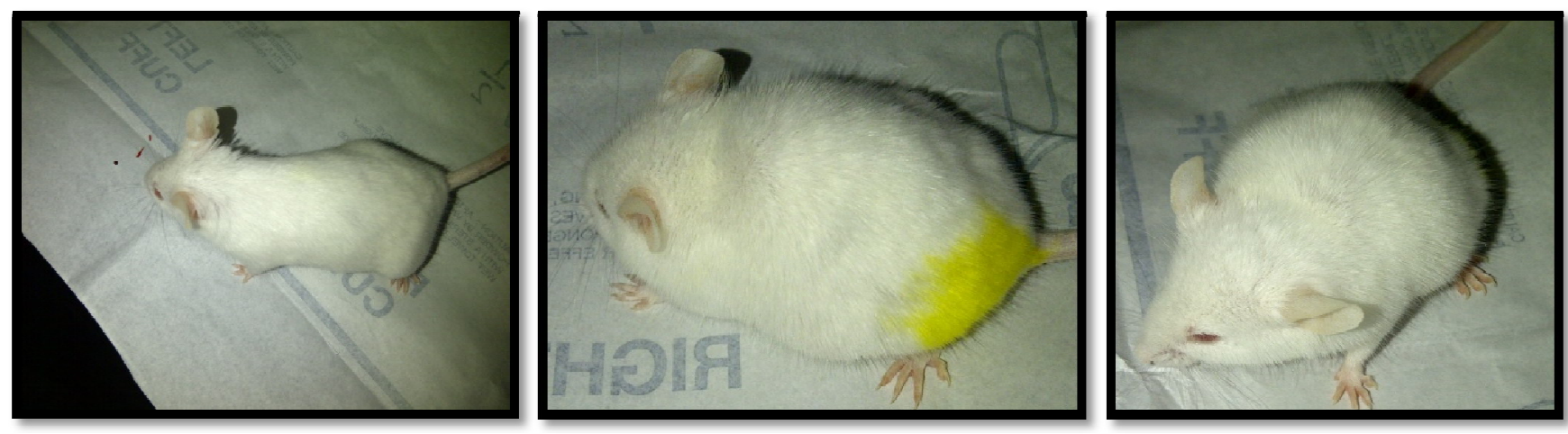

Figure 2

a. Mouse manifesting minimal symptoms of trypanosomiasis

b. Mouse manifesting moderate symptoms of trypanosomiasis

c. Mouse showing severe symptoms of trypanosomiasis

Figure 2: Caption a. Mouse infected with KETRI 4028 and treated with Isometamidium 1mg/ kg manifesting minimal symptoms of trypanosomiasis. Mouse showing a smooth hair coat, and general body condition is normal. The mouse was active and feed intake was high. Caption b. Mouse infected with trypanosome stabilate (KETRI 3985) and treated with Homidium $1 \mathrm{mg} / \mathrm{kg}$. The mouse showed shivering, listlessness and huddling in a corner. Caption c. An experimental mouse infected with KETRI 3984 and treated with Diminazene 20mg/ kg during a breakthrough infection stage at day 12 . The mouse showed raised hair coat, facial edema and emaciation. Feed intake was very low. Mice showed minimal movements inside the cage at advanced stage of trypanosomiasis. Severe clinical signs included shivering and muscle tremors. The mouse died later in the day.

\subsection{Parasita emia, PCV, and Body Scores in Experimentally Infected Mice}

\subsubsection{Parasitaemia}

There was significant difference ( $p$-value which was $<.001 \quad<\alpha=0.05)$ between KETRI 4028 and KETRI 3985 stabilates and control but the difference between KETRI 3984 and KETRI 4032 was not significant. On average, the first day of parasitaemia detection in blood for KETRI 4028, Control, KETRI 3985 and KETRI 4032 was $12^{\text {th, }} 3^{\text {rd }}$, $5^{\text {th }}$ and $6^{\text {th }}$ day respectively (figure 3). When treated with Homidium 1mg/ kg, KETRI 3985 stabilate had the highest mean parasitaemia levels all through the trial followed by KETRI 4032. KETRI 4028 stabilate had the lowest parasitaemia mean. 


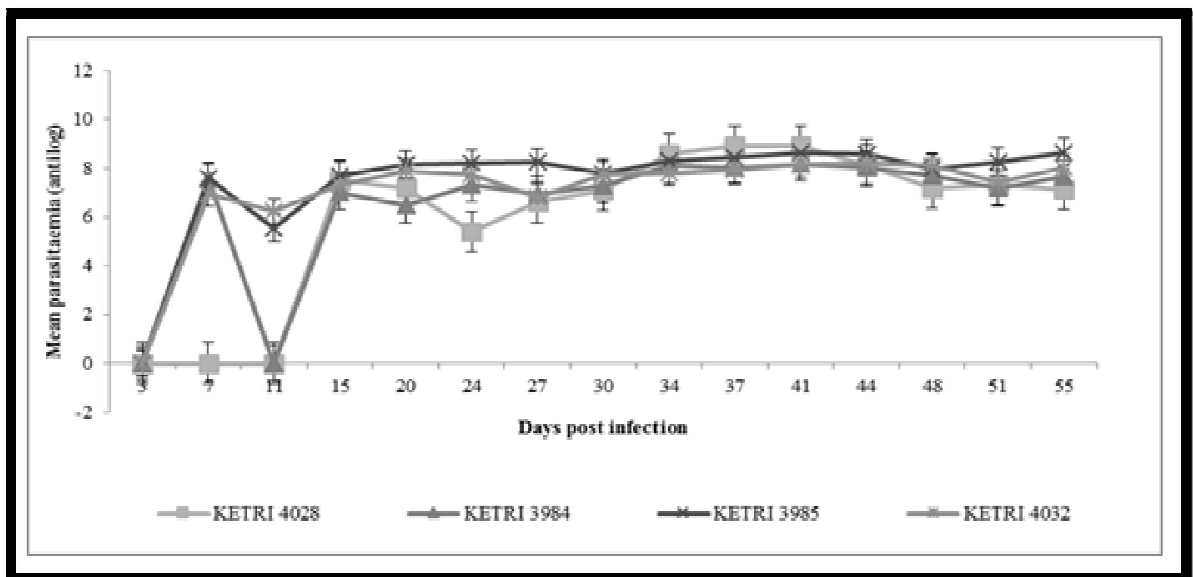

Figure 3: Mean Parasitaemia Levels Against DPI for The Different Trypanosome Stabilates Treated With Homidium 1mg/ Kg

When treated with Isometamidium 1mg/ kg, KETRI 4032 stabilate had the highest mean parasitaemia followed by KETRI 3985. KETRI 4028 stabilate had the lowest (Figure 4).

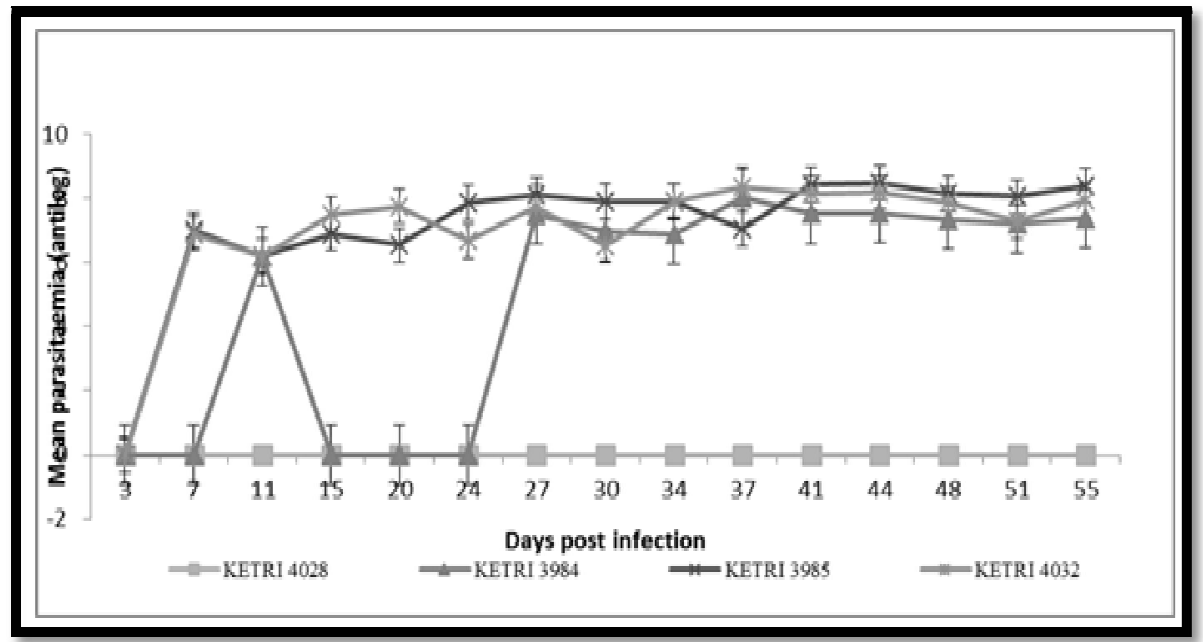

Figure 4: Mean Parasitaemia Levels Against DPI of the Different Stabilates Treated with Isometamidium $1 \mathrm{mg} / \mathrm{Kg}$

When treated with Diminazene 20mg/ kg, KETRI 3985 stabilate had the highest mean parasitaemia throughout the trial followed by KETRI 4032. KETRI 4028 stabilate had the least (figure 5).

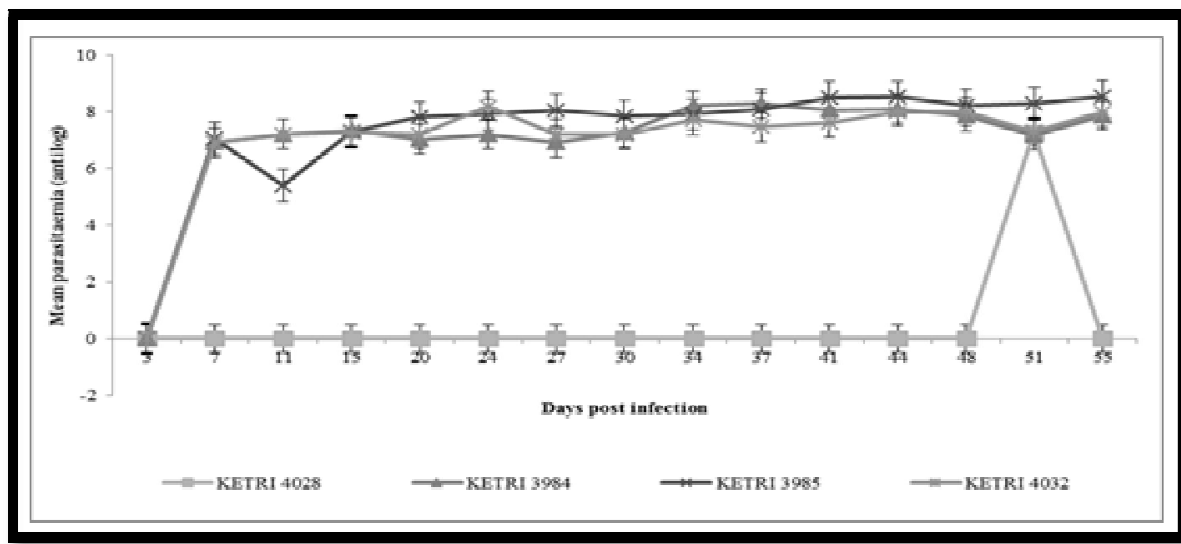

Figure 5: Mean Parasitaemia Levels Against DPI of the Different Stabilates Treated with Diminazene 20mg/ Kg 
When comparing parasitaemia levels of different stabilates in response to different drugs; the control group was most susceptible as it had the highest mean parasitaemia followed by groups treated with Homidium $1 \mathrm{mg} / \mathrm{kg}$ and Diminazene $20 \mathrm{mg} / \mathrm{kg}$. Isometamidium $1 \mathrm{mg} / \mathrm{kg}$ treated group was the least susceptible to KETRI 4028 isolate infection (figure 6).

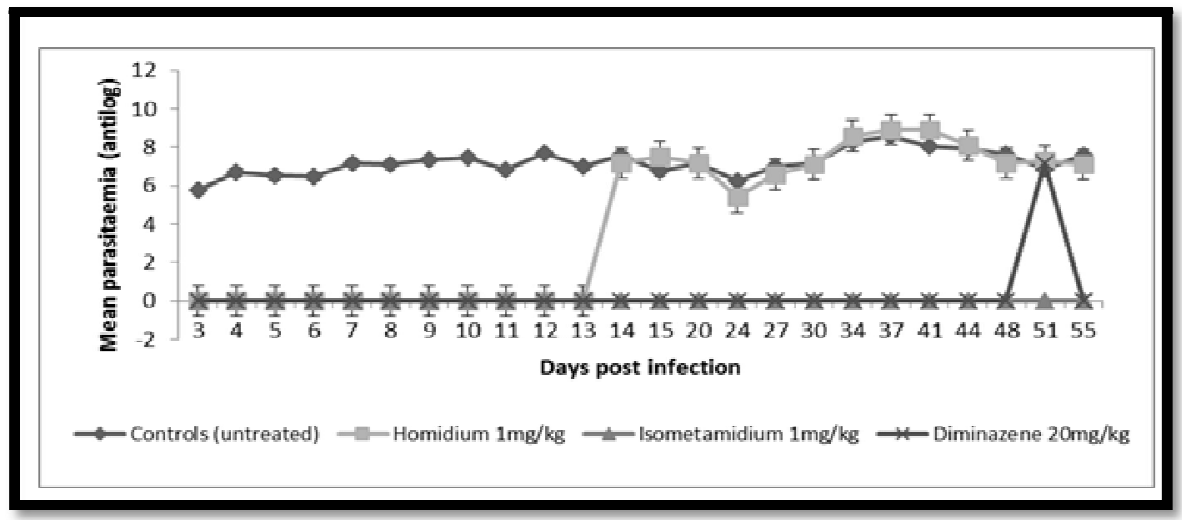

Figure 6: Mean Parasitaemia Levels Against DPI of KETRI 4028 Isolate Treated With Different Drugs and Control Group

Isometamidium $1 \mathrm{mg} / \mathrm{kg}$ treated group was the least susceptible to KETRI 3984 stabilate infection (figure 7). The control group and Diminazene $20 \mathrm{mg} / \mathrm{kg}$ treated group were most susceptible as they had the highest mean parasitaemia followed by group treated with Homidium $1 \mathrm{mg} / \mathrm{kg}$.

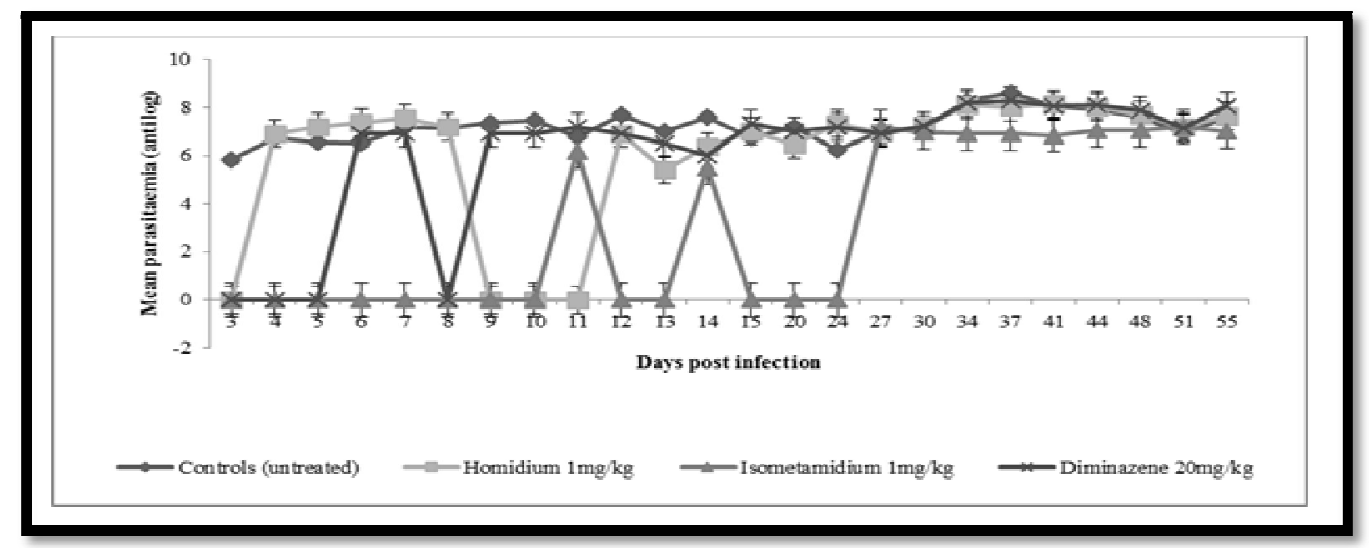

Figure 7: Mean Parasitaemia Levels Against DPI of KETRI 3984 Stabilate Treated With Different Drugs and Control Group

The group of mice treated with Homidium $1 \mathrm{mg} / \mathrm{kg}$ was the most susceptible to KETRI 3985 stabilate as it had the highest mean parasitaemia on average throughout the trial followed by Diminazene $20 \mathrm{mg} / \mathrm{kg}$ while Isometamidium $1 \mathrm{mg} / \mathrm{kg}$ treated group was the least susceptible (figure 8).

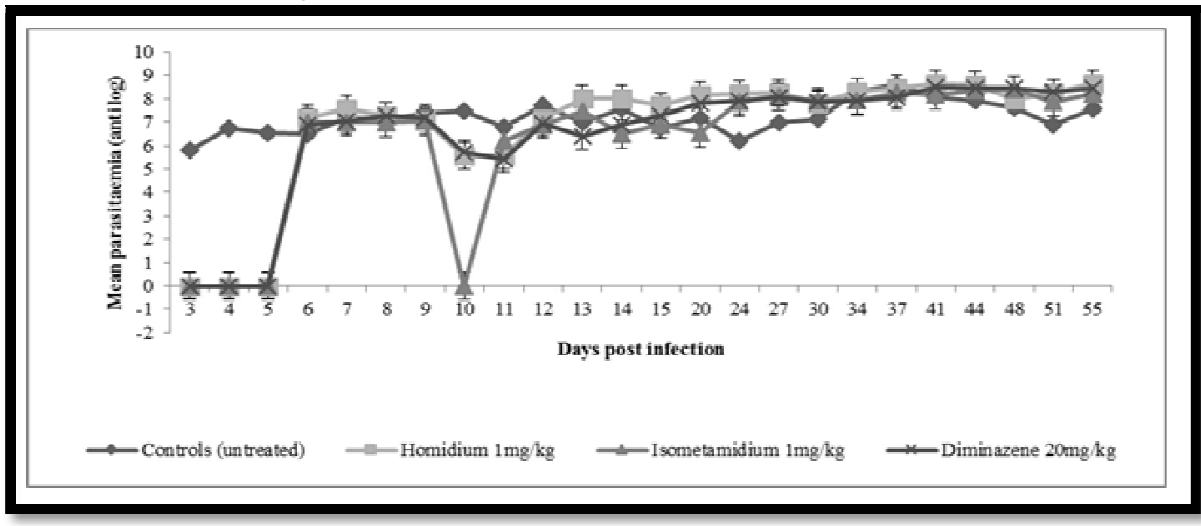

Figure 8: Mean Parasitaemia Levels Against DPI of KETRI 3985 Stabilate Treated with Different Drugs and Control Group 
The group of mice treated with Homidium $1 \mathrm{mg} / \mathrm{kg}$ was most susceptible to KETRI 4032 stabilate as it had the highest level of parasitaemia followed by the groups treated with Isometamidium $1 \mathrm{mg} / \mathrm{kg}$ and Diminazene $20 \mathrm{mg} / \mathrm{kg}$ (figure 9).

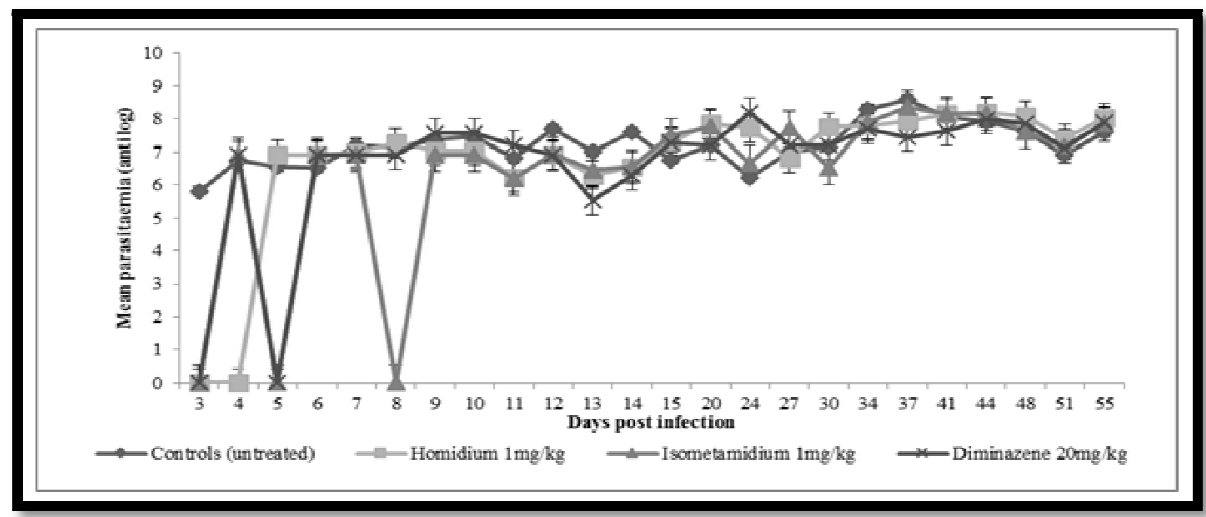

Figure 9: Mean Parasitaemia Levels Against DPI of KETRI 4032 Stabilate Treated with Different Drugs and Control Group

\subsubsection{PCV Level}

There was significant difference in PCV levels of different stabilates, $\mathrm{p}$-value $<.001(<\alpha=0.05)$. There was a significant change of PCV with time in mice infected with all the four stabilates. When infected with KETRI 3985, KETRI 4028, KETRI 3984 and KETRI 4032, Homidium1mg/ kg and Diminazene 20mg/ kg treated mice had lower mean PCV compared to those treated with Isometamidium 1mg/ kg which had the highest mean PCV during the evaluation period (figure 10, 11, 12).

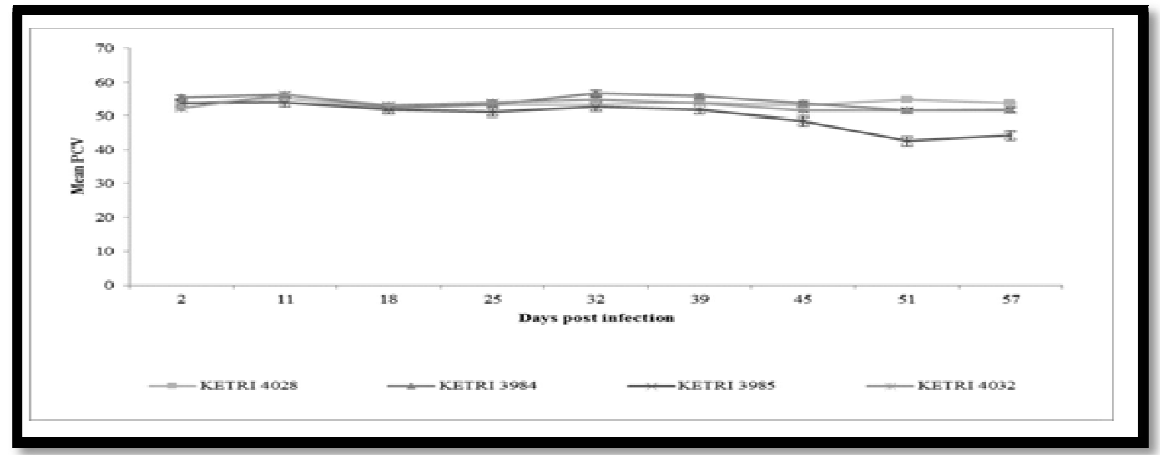

Figure 10: Mean Pcv Levels Against Dpi of the Four

Stabilates Treated With Homidium $1 \mathrm{mg} / \mathrm{Kg}$

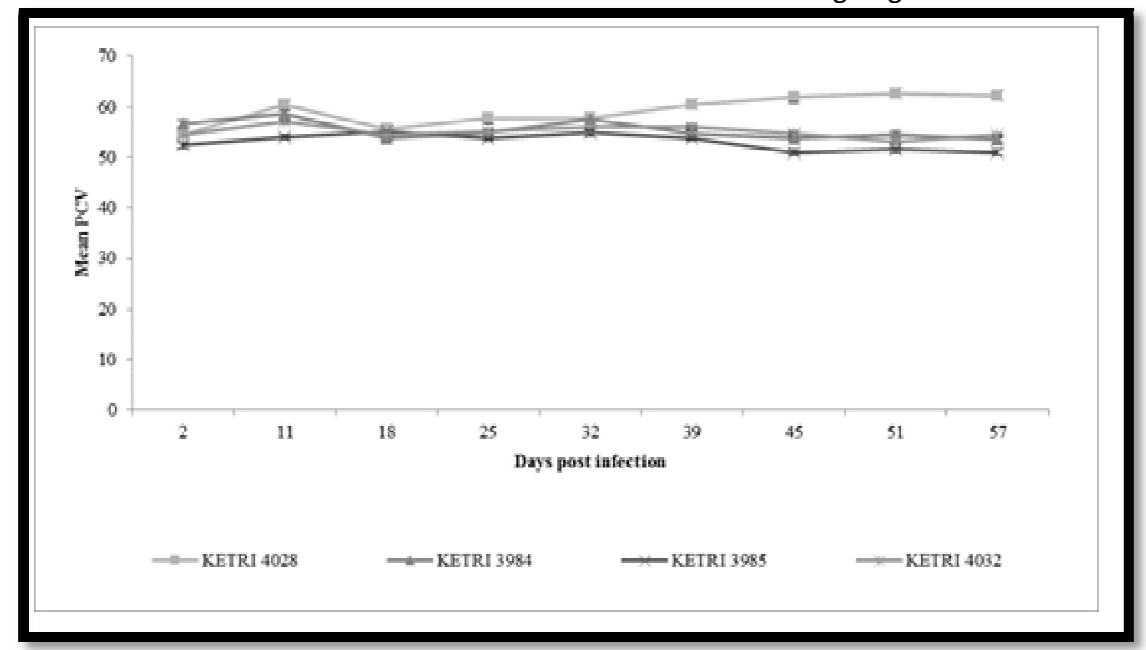

Figure 11: Mean PCV Levels Against DPI of the Four

Stabilates Treated With Isometamidium $1 \mathrm{mg} / \mathrm{Kg}$ 


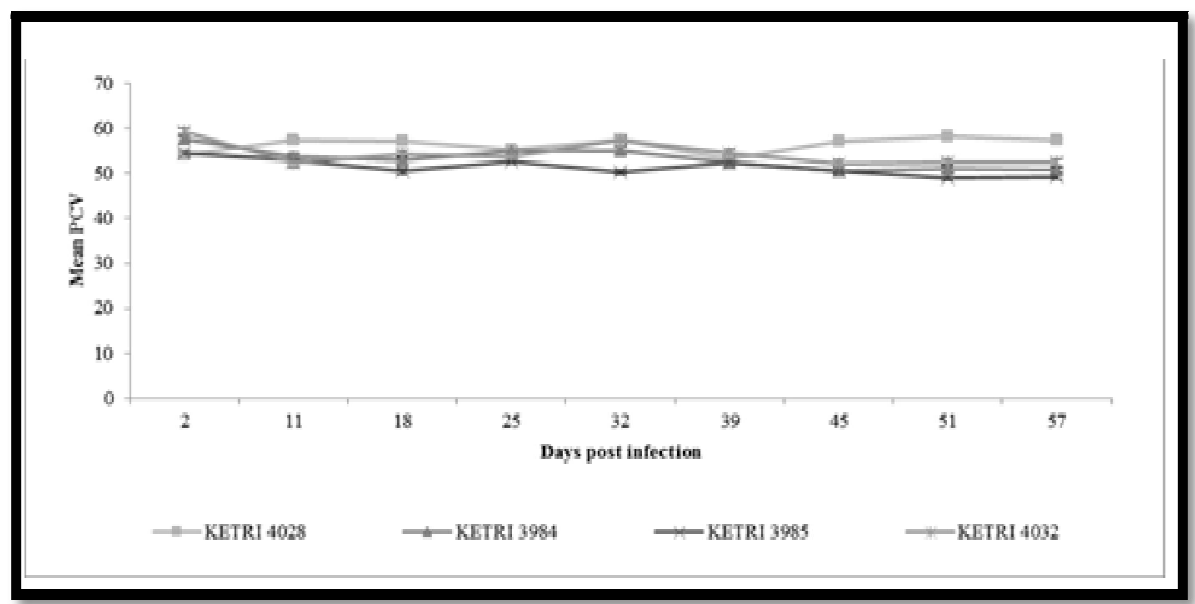

Figure 12: Mean PCV Levels Against DPI of the Four Stabilates Subjected To Diminazene 20mg/ Kg

The PCV levels of mice infected with different stabilates and treated with the three drugs showed p-value 0.049 $(<\alpha=0.05)$ which indicated a significant difference in PCV levels within groups of mice infected and treated with different drugs. After treatment with all the three drugs, KETRI 3985 and KETRI 4028 infected mice PCV levels were highest followed by KETRI 3984 and KETRI 4032 (figure 13, 14, 15, 16). The following graphs show that mean PCV in controls was significantly different from mice infected with different stabilates $p$-value $<.001(<\alpha=0.05)$, as they had the lowest mean PCV.

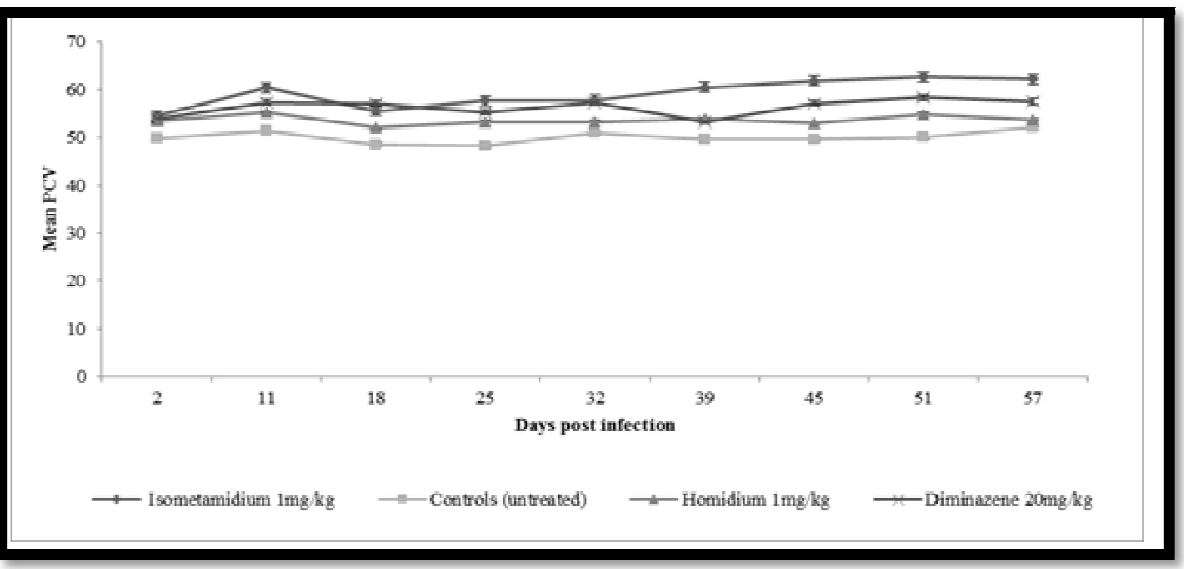

Figure 13: Mean PCV Levels Against DPI of KETRI 4028

Stabilate Treated With Different Drugs and Control Group

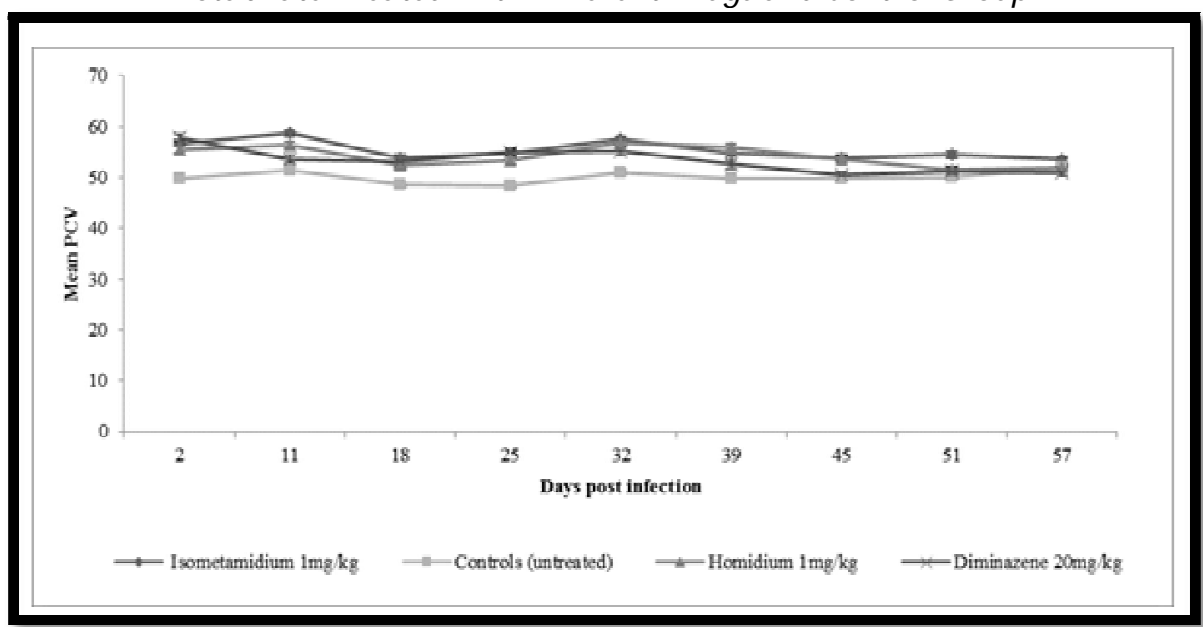

Figure 14: Mean PCV Levels Against DPI of KETRI 3984 Stabilate Treated with Different Drugs and Control Group 


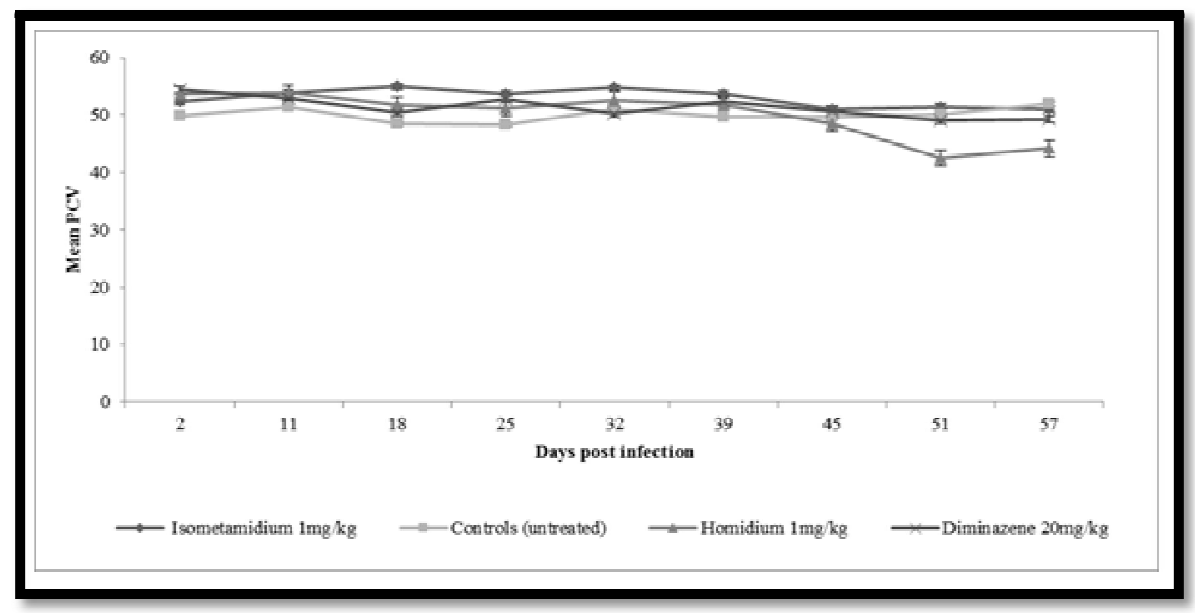

Figure 15: Mean PCV Levels Against DPI of KETRI 3985 Stabilate

Treated with Different Drugs and Control Group

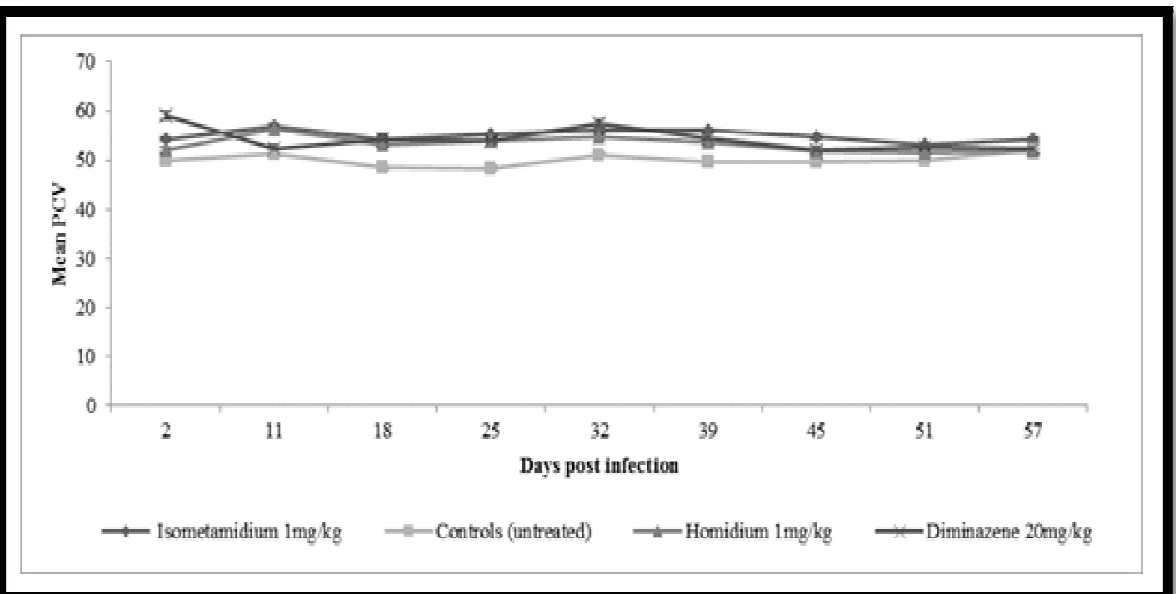

Figure 16: Mean PCV Levels Against DPI of KETRI 4032 Stabilate

Treated with Different Drugs and Control Group

\subsubsection{Body Weight}

There was no significant difference in body weights between mice infected with the different stabilates ( $p$-value 0.306 $(>\alpha=0.05)$. The body weights for all stabilates were similarly increasing during the trial except after ten days when KETRI 3985 had a significantly higher mean than the other stabilates when treated with the three drugs, as shown in figure 17, 18, 19.

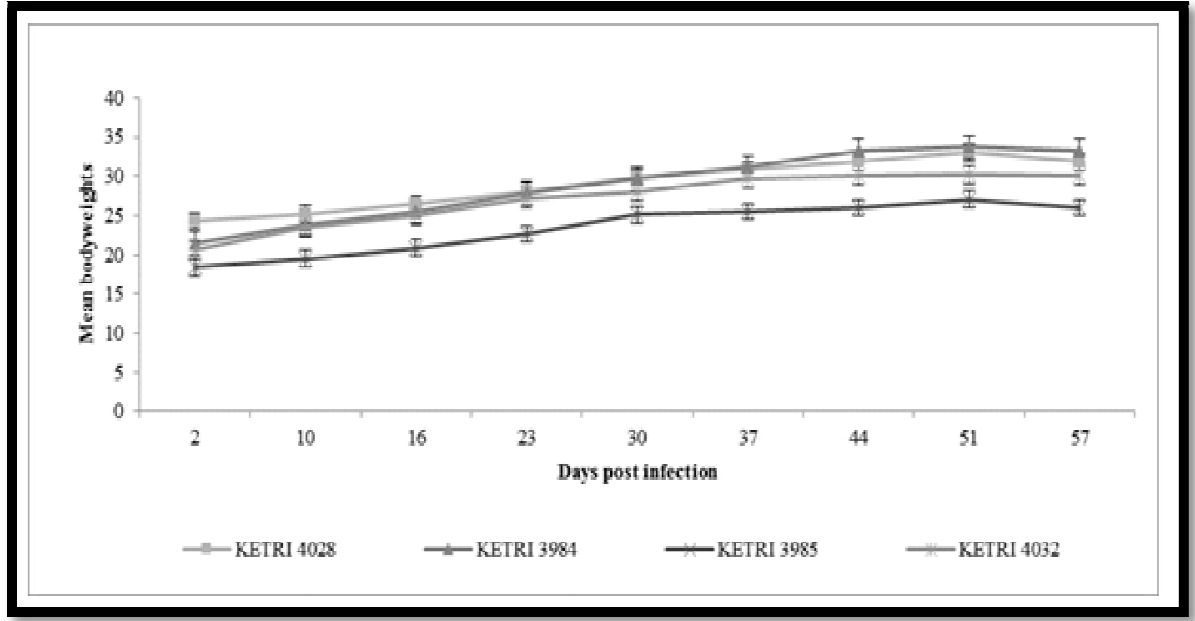

Figure 17: Mean Body Weights Against DPI of the Different Stabilates Treated With Homidium $1 \mathrm{mg} / \mathrm{Kg}$ 


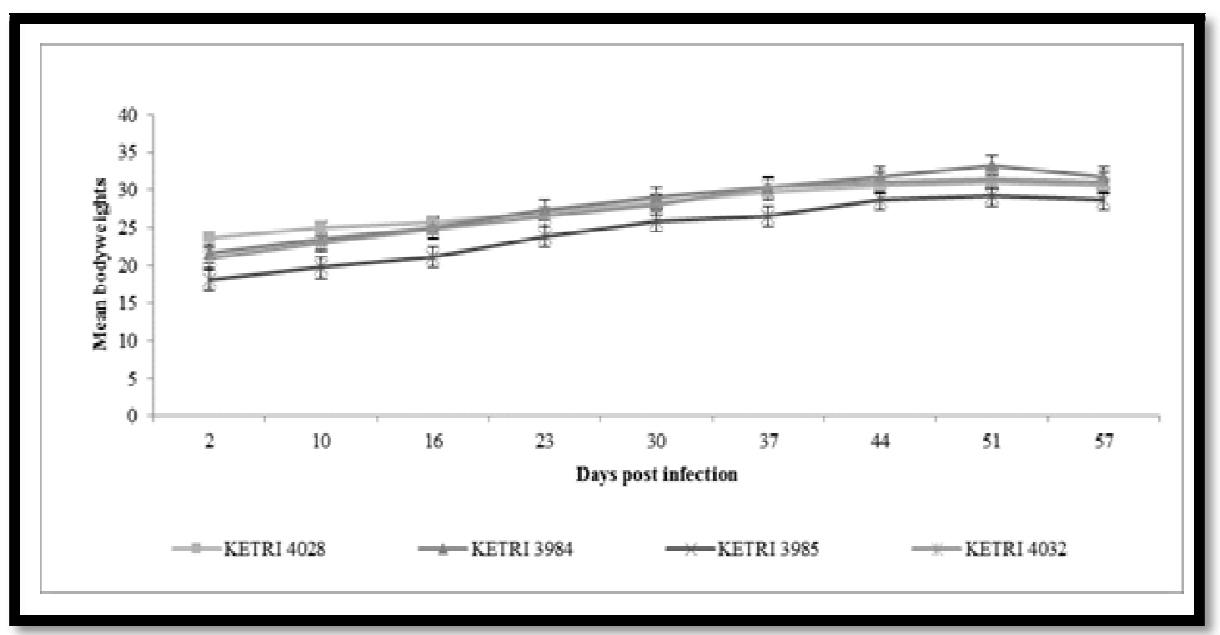

Figure 18: Mean Body Weights Against DPI of the Different

Stabilates and Treated with Isometamidium $1 \mathrm{mg} / \mathrm{Kg}$

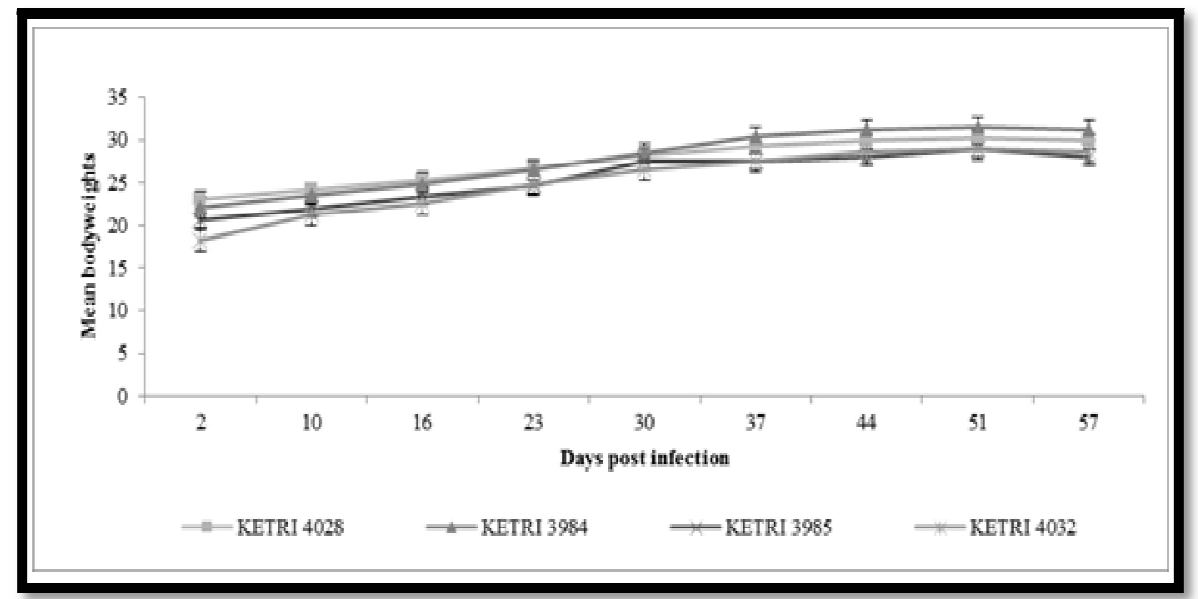

Figure 19: Mean Body Weights against DPI of the

Different Stabilates Subjected To Diminazene 20mg/ Kg

When comparing the three stabilates against different drugs; body weight changes within the time of study p-value was $0.161(>\alpha=0.05)$ which means that there was no significant difference in levels of body weights of the different drugs. The body weights of different groups of mice infected with KETRI 3985, KETRI 4028, KETRI 3984 and KETRI 4032 stabilates and treated with Homidium $1 \mathrm{mg} / \mathrm{kg}$, Isometamidium $1 \mathrm{mg} / \mathrm{kg}$ and Diminazene $20 \mathrm{mg} / \mathrm{kg}$ had a similar increasing trend during the trial period, which was not significantly different from control group (figure 20, 21, 22, 23)

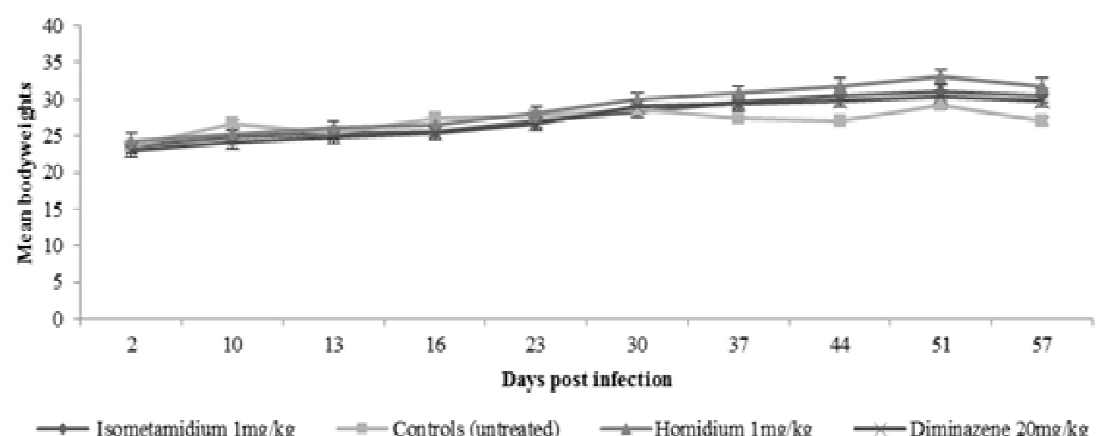

Figure 20: Mean Body Weights against DPI of Mice Infected with KETRI 4028 Stabilate Treated with Different Drugs and Control Group 


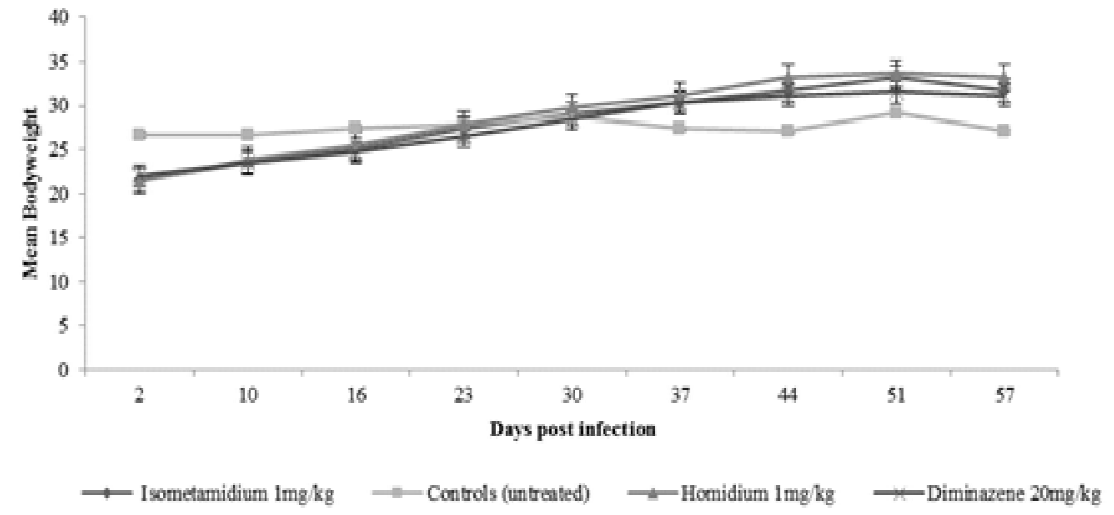

Figure 21: Mean Body Weights against DPI of Mice Infected with KETRI

3984 Stabilate Treated with Different Drugs and Control Group

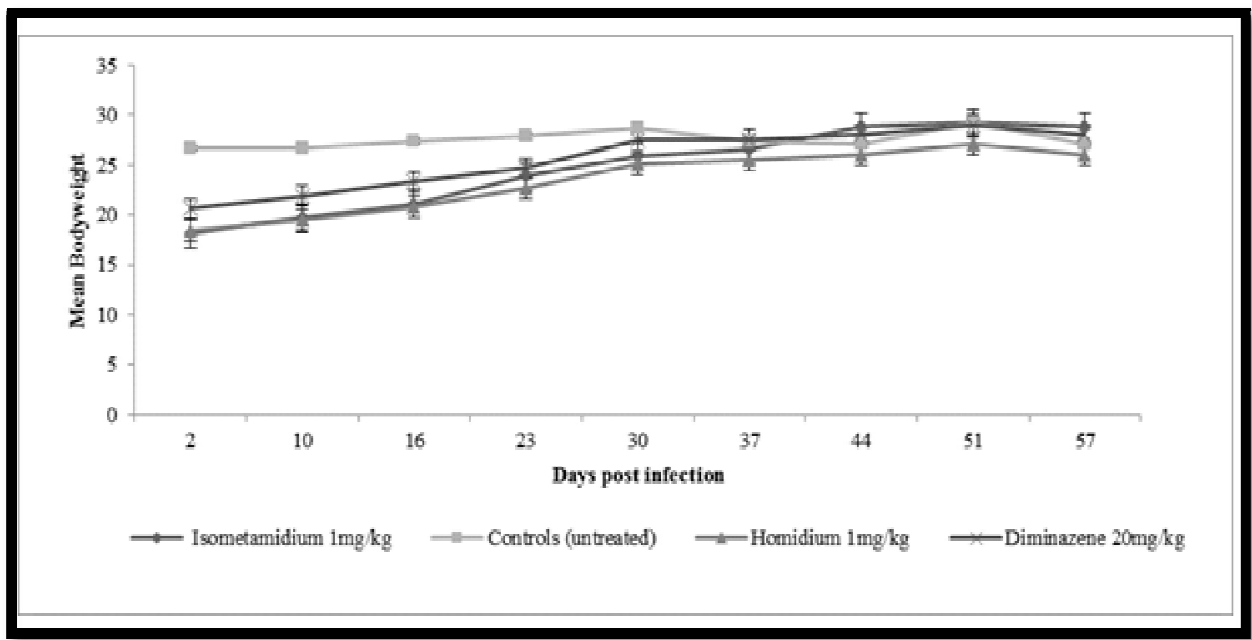

Figure 22: Mean Body Weights against DPI of Mice Infected with KETRI 3985 Stabilate Treated with Different Drugs and Control Group

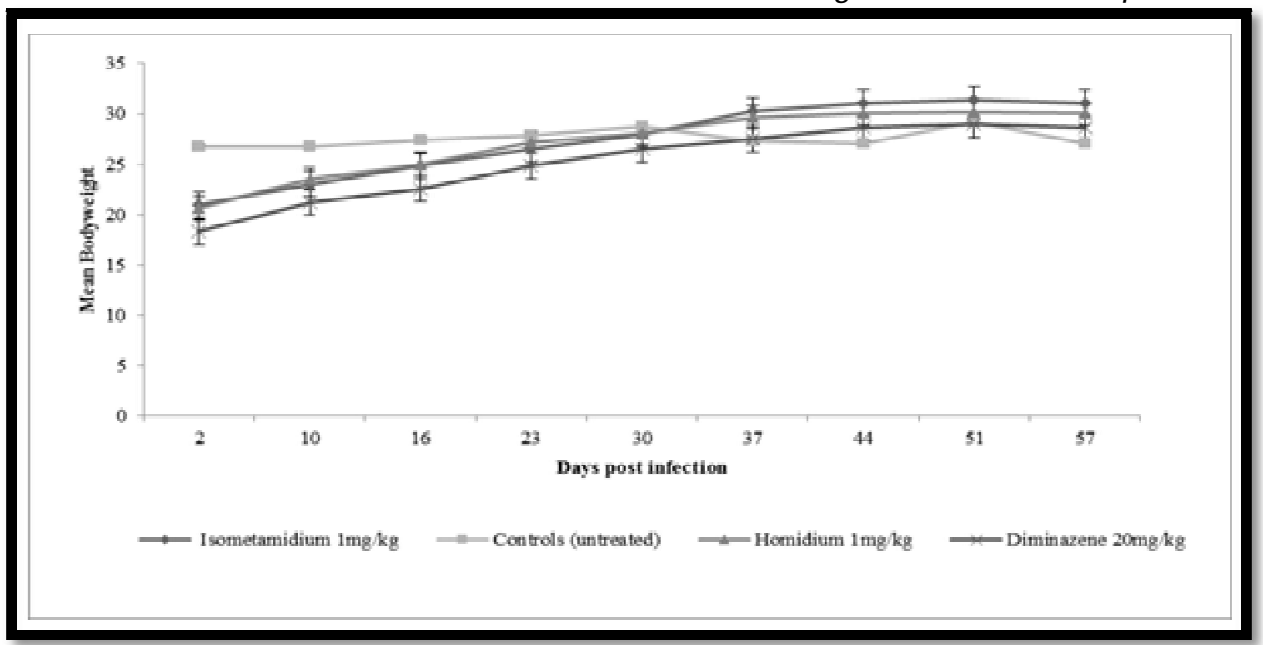

Figure 23: Mean Body Weights against DPI of Mice Infected with KETRI 4032 Stabilate Treated with Different Drugs and a Control Group 


\section{Discussion}

Clinical signs were characterized by raised hair coats in mice, poor body conditions (lethargy), facial and scrotal edema, loss of appetite, fast short breaths and pus from injured tails which would reduce survival times of mice results interdem with Korir et al., 2013 study. Most of the parasites showed a predominantly slender morphology, a free anterior flagellum with their posterior end being narrow and a sub terminal kinetoplast.

Experimental mice infected with KETRI 4028 and treated with Isometamidium 1mg/ kg showed mild clinical signs. This could have been associated with lower virulence of the stabilates unlike in the case of KETRI 3985 and treated with Homidium 1mg/ kg which had mild clinical signs. Mice infected with this stabilate had moderate disease symptoms while mice infected with KETRI 3984 and treated with Diminazene 20mg/ kg were severely affected by trypanosomiasis as the disease progressed.

Parasitaemia development in KETRI 3984 was faster compared to that in KETRI 4032, KETRI 4028 and KETRI 3985. Mean parasitaemia was the highest in mice infected with KETRI 3985 stabilate and treated with Homidium unlike in all other stabilates treated with the same drug. This could have suggested that KETRI 3985 stabilate was more resistant to Homidium at $1 \mathrm{mg} / \mathrm{kg}$ than the other stabilates. When treated with Isometamidium $1 \mathrm{mg} / \mathrm{kg}$, KETRI 4032 stabilate mean parasitaemia was highest compared to other stabilates treated with the same drug showing that it was more resistant to Isometamidium $1 \mathrm{mg} / \mathrm{kg}$ than the other stabilates. The same group of mice was resistant to Homidium $1 \mathrm{mg} / \mathrm{kg}$ as it equally showed a high parasitaemia. Diminazene 20mg/ kg treated mice and infected with KETRI 3985 stabilate had the highest mean parasitaemia which suggested that this stabilate was more resistant to Diminazene $20 \mathrm{mg} / \mathrm{kg}$ compared to the other two stabilates (KETRI 3984 and KETRI 4032). The control group was most susceptible to all stabilates followed by mice groups treated with Homidium 1mg/ kg and Diminazene 20mg/ kg. Parasitaemia levels of KETRI 3984, KETRI 3985 and KETRI 4032 were higher compared to KETRI 4028. Using Homidium 1mg/ kg, KETRI 4028 took 15 days before parasitaemia developed. KETRI 3984 showed waves oscillating from day 7 through day 11 in which it was observed to drop to zero in day 15 when it relapsed. Using Isometamidium 1mg/ kg, KETRI 3985 and KETRI 3984 stabilates parasitaemia developed in day 7 and day 11 respectively. The latter had parasitaemia waves oscillating to $27^{\text {th }}$ day and in some instances, it dropped to zero. Using Diminazene $20 \mathrm{mg} / \mathrm{kg}$, oscillation was observed in KETRI 4028 at 51 st day when parasitaemia developed which later dropped to zero in day 55. In KETRI 3984, slight oscillation was observed which did not drop to zero all through the 60 days of study. Different responses of immune system of mice infected with stabilates used in this study gave the difference in waves of parasitaemia. Different variable antigen types (VATs) of trypanosome stabilates to which immune responses is elicited especially in KETRI 3984, KETRI 3985 and KETRI 4032 could also be associated with the many waves observed in the graphs. PCV has been defined as measure of anaemia level (Kagira et al., 2005) in an animal. There was significant difference in PCV levels in the different stabilates treated with different drugs. There was a significant change of PCV with time in mice infected with all the four stabilates. The group of mice infected with KETRI 4028 and treated with the three drugs used in this study had the highest mean PCV indicating that it was sensitive to the drugs and blood PCV remained high. A high PCV level indicates that the parasitaemia levels were lowered by the drugs and blood cells kept high. When infected with KETRI 3985, KETRI 4028, KETRI 3984 and KETRI 4032, Control group of mice had the lowest mean PCV followed by mice treated with Homidium $1 \mathrm{mg} / \mathrm{kg}$ and Diminazene 20mg/ kg drugs.

The body weights of all groups of mice increased during the study even in the case of controls. Results from the analysis showed that body weights of mice unexpectedly increased with time despite being infected but were generally lower in KETRI 3984 and KETRI 3985, which is interdem with findings from other studies. This has been explained in other studies by the fact that the mice were still young at the beginning of the experiment when they had just been weaned and now were growing to maturity by the progression of the experiment, thus went on gaining weight (Korir et al., 2013). In the previous studies, general decrease in body weights 12 days post infection (Celine et al., 2005) have been shown which can be related to entry of trypanosomes in the CNS known to control body weight (Darsaud et al., 2004), unlike the case in this study. It was observed that infected mice whose parasitaemia levels were high had higher body weights but their PCV levels on the other hand were very low.

The relapse of infection by trypanosomes could occur majorly because the drugs used in this study were not able to target the relevant parts of the body where trypanosomes moved from the blood stream and sequestrated and death occurred in some cases. Where resistance was not a problem, a possible reason for infection relapse would be related to inaccessibility of the drugs to trypanosomes tissue stages of development (Al-Mohammed, 2008). Trypanosomes usually reside in structures including blood vessels of all organs, brain extravascular spaces, lung interstitials (Sudarto et al., 1990) and other extravascular sites (Matovu et al., 2003). Sites in which Diminazene aceturate (Diminazene $20 \mathrm{mg} / \mathrm{kg}$ ) in particular is not able to penetrate according to previous studies is the brain spaces (Peregrine, 1993) where relapse was possible. Relapse and death were also seen by some authors in their studies which was also the case in stabilates from Lamu. This study concurs with results from Dargantes (2010), in which treatment with Diminazene 20mg/ $\mathrm{kg}$ was found to be ineffective because relapse occurred on the 27th day post-treatment when used in rats and goats (Macaraeg et al., 2013) which was the case in this study. Reduced sensitivity to drugs could have been associated with change in genetic constitution, mutation and selection. Drug resistance in T. brucei has been shown in other studies (Matovu et al., 2001) which were associated with the parasite surviving in high concentrations not tolerable to the host, or the parasite may be naturally resistant due to other factors like 
host, vector or parasite. KETRI 4028 stabilate was sensitive to Isometamidium and Diminazene while stabilates KETRI 4032 from goat, KETRI 3985 from donkey and KETRI 3984 from donkey were resistant to the three drugs used in this study. This study has demonstrated the presence of T. b. brucei sub population that exhibits multiple drug resistance in mice. Earlier studies in Lamu, Kilifi and Kwale counties of the coastal Kenya have only demonstrated presence of T.vivax and T. congolense isolated from cattle that have shown multiple resistance to isometamidium, diminazene, homidium and quinapyramine (Mdachi, 2014, Ashiembi, 2013).

\section{Conclusion}

- Trypanosomes isolated from goats are resistant to Isometamidium $1 \mathrm{mg} / \mathrm{kg}$ commonly used in Lamu market in the recommended dosages according to manufacturers.

- There is presence of T. b. brucei sub populations circulating in Lamu that may exhibit multiple drug resistance and only $25 \%$ of the sub population may be sensitive to Isometamidium and Diminazene.

- The study recommends that use of Homidium should be discouraged while use of Diminazene and Isometamidium should be used with caution and only in cases that proper diagnosis of the disease has been done.

- Integrated trypanosomiasis control strategies should be advocated in Lamu County.

\section{References}

i. Al-Mohammed, H. I. (2008). Comparative In Vivo Activities of Diminazene, Suramine Quinapyramine and Homidium Bromide on Trypanosoma evansi infection in Mice. Scientific Journal of King Faisal University (Basic and Applied Sciences). 9: $1429 \mathrm{H}$.

ii. Ashiembi, S. (2013). Use of cELISA in verification of drug levels in the serum following treatment by various personnel in Lamu District. Research Journal of Agriculture and Environmental Management. 3(2): 106-136.

iii. Celine, C., Fredric, C., Annabelle, D., Raymond, C., Alain, B., \& Lionel, B. (2005). Clinical assessment of the entry into neurological state in rat experimental African trypanosomiasis. Acta Tropica. 95: 33-39.

iv. Connor, R.J., \& Van den Bossche, P., 2004. African animal trypanosome In: Coetzen, J.A.W; Tustin R.C. (Eds). Infectious diseases of livestock $2^{\text {nd }}$ edition. Oxford University press 1, 251- 296.

v. Dargantes, A. P. (2010). Epidemiology, control and potential insect vectors of Trypanosoma evansi (surra) in village livestock in southern Philippines. Dissertation. Murdoch University, Australia.

vi. Darsaud, A., Chevrier, C., Bourdon, L., Dumas, M., Burguet, A., \& Bouteille, B. (2004). Megazol combined with Suramin improves a new diagnosis index of the early meningo-encephalitic phase of experimental African trypanosomiasis. Tropical Medicine and International Health. 9: 83-91.

vii. El-arab, A.M., Girgis, S. M., Hegazy, E. M., \& El-khalek, A. B. (2006). Effect of dietary honey on intestinal microflora and toxicity of mycotoxins in mice. BMC Complementary and Alternative Medicine. 6: 1-13.

viii. Geerts, S., Holmes, P. H., Eisler, M. C., \& Diall, O. (2001). African bovine trypanosomiasis: the problem of drug resistance. Trends parasitology. 17(1): 25-8.

ix. Herbert, W.J., \& Lumsden, W.H.R. (1974). Trypanosoma brucei. A rapid matching method for estimating the host s parasitaemia. Experimental Parasitology. 40: 427- 431.

x. Kagira, J. M., \& Maina, N. W. (2007). Occurrence of multiple drug resistance in Trypanosoma brucei rhodesiense isolated from sleeping sickness patients. Onderstepoort Journal of Veterinary Research. 74:17-22.

xi. Kagira, J. M., Maina, N. W., Thuita, J.K., \& Hau, J. (2005). Influence of cyclophosphamide on the haematological profile of Laboratory Bred African Soft-furred rats (Mastomys natalensis). Laboratory Animal Science. 32: 153-158.

xii. Kobo, P.I., Erin, P.J., Suleiman, M.M., Aliyu, H., Tauheed, M., Muftau, S., \& Mamman, M. (2014). Antitrypanosomal effect of methanolic extract of Zingiber officinale (ginger) on Trypanosoma brucei brucei-infected Wistar mice. Veterinary World. 7(10): 770-775.

xiii. Korir, S.C., Mburu, J., Shivairo, R.S., Serem, E., Arasa, G., Cheruiyot, J., Chome, J., \& Mdachi, E. (2013). Comparison of drug sensitivity pathogenicity of Trypanosoma brucei rhodesiense stabilates with their respective clones originating from Busia and Busoga. Journal of Natural Science Research. 3: 20-25

xiv. Macaraeg, B. B., Jonathan, V. L., Nancy, S. A., \& Claro, N. M. (2013). In-vivo assessment of the effects of trypanocidal drugs against Trypanosoma evansi stabilates from Philippine water buffaloes (Bubalus bubalis). Veterinarski Arhiv. $83(4), 381-392$.

xv. Matovu, E., Mhairi, S., Federico, G., Reto, B., Pascal, M., Lynsey, W., Richard, B., Enyaru, J., Barret, M., Ronald, K., Thomas, S. and Harry, K. (2003). Mechanism of Arsenical and Diamidine Uptake and Resistance in Trypanosoma brucei. American society for microbiology. 2(5):1003-1008.

xvi. Matovu, E., Thomas S., Enyaru, C.K., \& Ronald K. (2001). Drug resistance in Trypanosoma brucei spp., the causative agents of sleeping sickness in man and nagana in cattle. Microbes and infection.3(9):763-770.

xvii. Mdachi, R.E. (2014). Impact of drug resistance in disease control in coastal Kenya in Epidemiological Evaluation of Trypanosomiasis the control in Cattle, Lambert academic Publishing, Germany.

xviii. Mdachi, R.E., Mukiria, P.W., Nyamwaro, S.O., Thuita, J.K., \& Murilla, G.A. (2006b). Evaluation of tsetse and trypanosomosis situation in Lamu district of the coast province. Development, evaluation and promotion of cost 
effective integrated tsetse and trypanosomosis control strategies in the coastal region of Kenya, Technical report No 2, Trypanosomiasis Research Centre.

xix. Mdachi, R.E., Mukiria, P.W., Nyamwaro, S.O., Thuita, J.K., \& Murilla, G.A. (2006b). Evaluation of tsetse and trypanosomosis situation in Lamu district of the coast province. Development, evaluation and promotion of cost effective integrated tsetse and trypanosomosis control strategies in the coastal region of Kenya, Technical report No 2, Trypanosomiasis Research Centre.

xx. Mdachi, R.E., Mukiria, P.W., Nyamwaro, S.O., Thuita,J.K., \& Murilla, G.A (2006). Tsetse and trypanosomosis control technologies used at the coastal region: Farmers perception. Development, evaluation and promotion of cost effective integrated tsetse and trypanosomosis control strategies in the coastal region of Kenya, Technical report No 1, Trypanosomiasis Research Centre.

xxi. Murilla, G. A., Kariuki, N., Thuita, K., Gitonga, P., Kahiga, D., Joanna, E. A., \& Ndung'u, M. (2014). Kenya Trypanosomiasis Research Institute Cryobank for Human and Animal Trypanosome Stabilates to Support Research: Opportunities and Challenges. PLoS Neglected Tropical Diseases. 8(5): e2747.

xxii. Murilla, G. A., Phoebe, M., Mdachi, R., Mutuku, J., \& Wanjala, K. (2010). Epidemiology and control of donkey trypanosomiasis and their vectors in the Lamu Island. Equine Veterinary Journal. 7: 186-197.

xxiii. Peregrine, A. S. (1993). Chemotherapy and delivery systems: haemoparasites. Veterinary parasitology. 54: 223-248.

xxiv. Shimelis, D., Sanguwan, A.K., \& Getachew, A. (2008). Assessment of trypanocidal drug resistance in cattle of the Abay (Blue Nile) basin areas of Northwest Ethiopia. Ethiopia Veterinary Journal. 12: 45-59.

xxv. Sudarto, M. W., Tabel, H., \& Hainies D. M. (1990). Immunohistochemical Demonstration of Trypanosoma evansi in Tissues of Experimentally Infected Rats and a Naturally Infected Water Buffalo (Bubalus bubalis). The journal of Parasitology. 76(2): 162-167.

xxvi. Waren, N., Cadosry, P., Fernandez, K., \& Abgail, M. (2011a). Molecular detection of Trypanosoma evansi in cattle from Quirino Province, Philippines. Veterinarski Arhiv. 81 (5), 635-646. 